\title{
4 \\ World wars and village revolutions
}

World War II made a deep impression on the people of the Admiralty Islands, but they began getting to know Europeans, albeit in much smaller doses, hundreds of years earlier. Incorporation into the European world, even at its far edges, made them unwilling actors in two world wars. Their involvement with the European world inspired some Admiralty Islanders to reflect on their indigenous cultures, find them wanting, and propose truly revolutionary changes. Many were especially eager to alter the affinal exchange system, a radical aim since it was at the very centre of indigenous life, as discussed in the previous chapter. There was probably plenty of discontent with the demands and implications of this institution well before contact with outsiders, but it took new experiences and exampleseven if only dimly understood - to stir systematic opposition. Most advocates of change had little success, but what we know of their efforts shows not only the extent to which Paliau lived in an era of widespread cultural ferment - his was not an isolated voice—-but also how much his vision and talent distinguished him from fellow champions of change.

\section{European contacts and colonial society through World War I}

European explorers had noted the group of islands later named the Admiralty Islands as early as the sixteenth century, but for many decades the European presence in the Admiralties was limited and sporadic. In 1884, the German New Guinea Company (Deutsche Neuguinea-Kompagnie) obtained 
a charter from the German government to do business and provide civil administration in the areas of New Guinea claimed by Germany. These were known at the time as the German Solomon Islands, Kaiser Wilhelmsland (mainland New Guinea stretching south to the border with Britain's claim), and the Bismarck Archipelago (encompassing the Admiralty Islands, New Britain, New Ireland, and numerous smaller islands). In their trade with New Guineans, Europeans sought shells for manufacturing buttons and jewellery, usually from the nacre or mother-of-pearl; bechede-mer, an edible marine invertebrate, sometimes called sea cucumber; and coconuts for producing coconut oil from the dried meat or copra. ${ }^{1}$

James and Achsah Carrier (1989: 75) note that in the early twentieth century, Admiralties people were notorious for attacking trading vessels and stations, looting them, and killing both white traders and their Pacific Islander workers. The most active raiders were the Titan speakers, who may have been defending their own prerogatives as the region's premier maritime traders. Titan raiders sometimes captured firearms, which probably exacerbated intra-indigenous warfare. The Germans attempted to quell raiding by shelling villages from military vessels, but with little lasting effect until Germany established a stronger, more consistent presence and Admiralties people established stronger economic ties with the Europeans. ${ }^{2}$

For many years, German efforts at governing the Admiralties were negligible. It was not until 1911 that Germany set up an administrative post at Lorengau. At the same time, however, German companies were establishing coconut plantations throughout Germany's New Guinea domain and recruiting New Guinean labourers. ${ }^{3}$ Plantations generally preferred labourers from distant regions, to make it more difficult for them to decamp and return home. Under both the German and Australian administrations in the Admiralties there were also penal sanctions for New Guineans breaking their labour contracts, including fines, flogging, and imprisonment. Although New Guinean migrant workers had contracts (usually committing them to two years of work), recruiting sometimes was little better than slaving, and New Guineans often signed or, more often, simply made their marks on

1 Not all the trade was in European hands, however. Carrier and Carrier (1989: 75) observe that the Japanese merchant Isokide Komine was a major figure in trade in the Bismarck Archipelago as early as 1902 .

2 The Carriers (1989) base their account of these aspects of history in the Admiralties on the work of Biskup (1970), King (1978), and Sack and Clark (1979) in addition to their own field research in the Admiralties.

3 Again, we rely on the Carriers (1989: 76), who draw on Firth (1973), King (1978), and Sack and Clark (1979). 
contracts under duress. ${ }^{4}$ Even so, to obtain both European goods— such as steel tools, cloth, and tobacco — and cash, many New Guinean men went to work for the Europeans. Both German and Australian administrations also imposed a head tax on adult male villagers to create a need for cash obtained through wage work. Carrier and Carrier (1989: 76) point out that many Admiralties people avoided plantation work if possible, preferring work as domestic servants, on the crews of European vessels, or in the colonial police, an armed force composed of New Guineans, some of whom served as lower-level officers under white leadership. ${ }^{5}$

Christian missionaries were as active as traders and labour recruiters. German Catholic missionaries of the Sacred Heart were the first to create an outpost in Manus, initially at Papitalai on Los Negros, in 1913, and then in Bundralis, a village on the north coast, in 1916 (Carrier and Carrier 1989: 77). The Titan of the south coast of Manus Island adopted Christianity about 1930, shortly after Mead's and Fortune's sojourn in Pere village. Although most Christian converts never truly discarded their indigenous beliefs and practices, their affiliation with Roman Catholicism was voluntary. They assumed the missions played a central role in white society and that the new cosmologies and rituals were inseparably linked to white wealth, power, and longevity (as will be clear when we address borrowing from Christianity in the Paliau Movement). Also, unlike material wealth and political authority, Christianity was something the Europeans were willing, even eager, to share.

The Lutheran Evangelical Mission (also known as the Liebenzell Mission of the USA) established its first outpost in New Guinea on Manus in $1914 .{ }^{6}$ Seventh-day Adventist missionaries entered the Pacific Islands in the 1920s and established themselves on Manus not long after. ${ }^{7}$ By the beginning of World War II, most of the indigenous people of the Admiralty Islands had joined the congregations of one mission or another. ${ }^{8}$

\footnotetext{
4 Rowley (1965: 104-6) discusses major features of labour recruitment in colonial New Guinea.

5 Both the German and Australian administrations recruited New Guineans to serve in armed police forces.

6 Imi.tripod.com/pngmis.html.

7 encyclopedia.adventist.org/.

8 Christian missionaries first arrived in what is now Papua New Guinea in 1847 and they keep coming. In addition to Seventh-day Adventists, the Liebenzell Mission, and Catholics of diverse orders, PNG has drawn the London Missionary Society, Wesleyan Methodists, Lutherans, Anglicans, the South Seas Evangelical Mission, the Church of the Nazarene, the Apostolic Church, the New Tribes Mission, the Foursquare Gospel Church, the Christian Revival Crusade, the Philadelphia Church, and many others. The preamble to PNG's constitution pledges the country to Christian principles, but there is no state religion. Although most Papua New Guineans identify themselves as Christians, small numbers are followers of Buddhism, Hinduism, Islam, and Judaism (Gibbs 2014).
} 
When World War I broke out in 1914, Australian military forces encountered little opposition from German personnel in the Bismarck Archipelago (Hiery 1995: 25). The Australian New Guinea Administrative Unit (ANGAU) governed the former German New Guinea for the duration of the war and, following the war, until the newly formed League of Nations gave the responsibility to Australia. Australian civil administration of what now became the Mandated Territory of New Guinea replaced ANGAU in 1921 (Souter 1963: 124-6).

In the Admiralties, Australia established government headquarters at Lorengau. The new administration adopted the German model for indirect rule, under which the colonial administration appointed New Guineans to act as its representatives in each village. The German administration took the titles for these officials from an indigenous language of New Britain, where Germany had established one of its first outposts. The highest ranking appointed official was the luluai, understood to mean a kind of chief. Someone of high rank in the indigenous community was usually chosen for this post, as the colonial imprimatur alone was not enough to give him authority among his peers. He was assisted by the tultul, a person often chosen in part for his ability to speak Melanesian Pidgin and thus to interpret between the luluai and Europeans. A paramount luluai was appointed for the north coast and another for the south coast to serve as intermediaries between the administration and the many village luluai in their regions. ${ }^{9}$ But this only slightly lengthened the chain between the administration and individual villages and had little effect on inter-village relations. The political ties among villages remained insubstantial.

Although the Australian civil administration that replaced ANGAU in 1921 brought some improvements in New Guinean - Australian relations (Hiery 1995: 86, 92), Australia’s liberation of New Guinea from German rule was not liberation from unapologetic white supremacy and colonial rule for profit (Hiery 1995: 65-97). But the combination of stronger colonial government and New Guineans' greater direct involvement with Europeans in the economic sphere and via the Christian missions gradually reduced both violent clashes between the colonial government and local people and diminution, if not complete cessation, of fighting among local groups. The indigenous people of several Pacific Islands locales had their own reasons for seeking an end to chronic warfare (Rodman 1979: 19-22), some of which may also have been at work here.

9 As indicated in our note on spelling and pronunciation at the beginning of this volume, Tok Pisin spelling does not distinguish plural from singular nouns. 
Whatever the other effects of what historians and anthropologists often call the 'pacification' of the Admiralties, it did afford local people greater freedom of movement than had been possible before.

The other significant new freedom the colonial regimes offered was the opportunity young men now had to leave their villages and work for Europeans. Despite the often harsh conditions of such work, travelling beyond the narrow limits set by the political fragmentation of the indigenous world and seeing a sample of the European world up close became a rite of passage for younger men.

In the villages, life continued to centre around fishing, gardening, and ceremonial exchange. Migrant workers might have used the goods and money they brought home to mount the exchanges needed to acquire a wife and achieve full adult status, freeing them from the need to become indebted to their elders. But their elders usually appropriated the wealth young men brought home for their own exchanges, rendering the returned workers as dependent on their elders for position in society as before. The only escape was to leave the village permanently. This had been next to impossible in the past, and it was still too radical a measure for most. So the European currency and manufactured goods the young men brought home flowed to the elders and through them into the local system of arranged marriage and affinal exchange. (Although the Christian missions had some success in suppressing polygamy, the basic marriage system remained intact.) Alongside the strings of dogs' teeth and shell beads hung on the counting lines, the displays of wealth at exchange ceremonies began to feature European tools, cloth, and heavy strings of Territory shillings. ${ }^{10}$

But while elders and the lapan could turn these new sources of wealth to their advantage, they could not control the flow of new ideas. Working on plantations, crewing European trading ships, working as domestic servants, or-in some highly significant instances for the Admiraltiesserving in the colonial police brought together New Guineans from all over the Territory. They learned from each other of conditions and events in other parts of the Territory and began to shape a pan-New Guinean

10 Territory shillings were distinct from Australian shillings. The former had their own design as well as holes in their centres through which the coins could be strung together. 
culture. They abstracted from the similarities they found among their various home cultures an idea of a larger New Guinean way of life and its essential contrasts with the ways of the whites.

This was the situation in the Admiralties just prior to World War II. Colonial government had been imposed and accepted, although it would have been easy not to notice. Mead (1977: 63) reported in 1928 that the white population of Lorengau numbered only about two dozen. This had increased to only about 50 when World War II broke out (Jackson 1976: 388, cited in Carrier and Carrier 1989: 76). But warfare and raiding among indigenous groups had virtually ceased. The introduction of European-style currency was an important development, for it began the long and complex process of creating a cash economy, although people's desires for European goods far exceeded their capacity to purchase them with cash. Affiliation with Christian missions was spreading rapidly, without necessarily weakening the hold of old belief systems. Opportunities to leave the village to work had made it more difficult for village leaders and elders to bring younger men fully under their control. Despite the gross social inequalities and occasional violence to which both Germans and Australians subjected New Guineans, colonial authorities expropriated very little land-most villages lost little or none-and most people regarded as improvements to their condition the opportunities to work for Europeans, the presence of European towns, missions, and plantations, and access to European goods and money.

\section{World War II: White wealth descends on Manus}

What was then the Empire of Japan entered World War II by bombing the American naval base at Hawai'i's Pearl Harbor on 7 December 1941. Japanese forces soon sought to sweep down to Australia via Australian New Guinea. Having already overcome Australian resistance at Rabaul and bombed several Australian towns on mainland New Guinea, Japanese forces encountered little opposition to occupying the Admiralty Islands in April 1942. They built landing strips on Los Negros Island, set up artillery on the coast, and established garrisons. Assuming they would make New Guinea an enduring part of a greatly expanded empire, they started a school to teach the Japanese language to Admiralty Islanders. In 1953, the Mead party met Manus people who had lived through the occupation who told 
them that the Japanese had announced that, henceforth, they would be their rulers. Yet the Mead party found little evidence of enduring Japanese influence. People told stories about the distinctive customs of the Japanese and of how they forced villagers to work for them without compensation under the threat of cruel discipline. A number of those who had attended the school also could perform some Japanese songs. However, little else seemed to have survived to remind anyone of the occupation. It is possible that fear of being thought a Japanese collaborator encouraged expunging the record, or that events following the expulsion of the Japanese may have simply overshadowed the preceding years.

While the occupation had few obvious direct effects on local life, it had several important indirect effects. The Australians in New Guinea, easily routed by the Japanese, and the European missionaries, who had been evacuated as the Japanese approached, suffered some loss of prestige. But numbers of Admiralty Islanders trained by Christian missionaries as Bible teachers, or what Catholics called native catechists, carried on in the village churches, perhaps thereby acquiring a greater sense of independence. Several of the leaders of the Paliau Movement had been either Catholic catechists or Lutheran Evangelical teachers during the years of the war. Many Admiralty Islanders working on New Ireland or New Britain at the outbreak of war were stranded there for the duration in Japanese custody. This lengthened and intensified their contact with New Guineans from other parts of the Territory and seems to have nurtured wider ethnic identities. In the stories they told of their internment, Admiralty Islanders spoke of each other simply as Manus, dropping the invidious distinctions between Titan, Usiai, and Matankor. Younger men also told of how they discussed plans for changing the old way of life and subverting the authority of their elders on their return home.

The Japanese occupation of the Admiralties lasted less than two years. The first wave of a decisive American attack began on 29 February 1944. By the end of March, organised Japanese resistance had ended, at the cost of over 4,000 Japanese and just over 300 American deaths. ${ }^{11}$ Casualties among the Manus people were mercifully few considering the scale of the fighting. The official ANGAU report on the campaign lists one indigenous

11 Several sources give approximately these same figures. They include the Pacific War Online Encyclopedia (pwencycl.kgbudge.com/A/d/Admiralty_Islands.htm) and The Daily Chronicles of World War II: MacArthur Kicks Off Admiralty Islands Campaign (ww2days.com/macarthur-kicks-off-admiraltyislands-campaign.html). 
islander killed in combat and one wounded (many islanders served in combat, several of them receiving commendations), three men killed by the Japanese 'not in action', 20 men and women 'accidentally killed', and 34 'accidentally wounded' (ANGAU 1944: Appendix V). ${ }^{12}$

As soon as the fighting ended, American construction battalions began installing a military infrastructure that dwarfed that of the Japanese. Lachlan Strahan (2005: 10-11) writes that by October 1944 the Allied installation on Manus was 'one of the world's largest naval bases, with hundreds of warships anchored in Seeadler Harbor' (a name bequeathed by the German administration to the deepwater harbour embraced by the main island and Los Negros). The Americans expanded the Japanese airstrip at Momote and, near the present-day village of Mokerang, built a new 6 kilometre long airstrip (20,000 feet), capable of handling heavy bombers. The entire base covered some 64 square kilometres (about 25 square miles) and included housing for 150,000 troops. Over 1 million American military personnel at least paused there over the course of the war. The very success of the Allied war effort launched from this base, however, made it a fleeting presence. By late 1947, it had, in Strahan's (2005: 36) words, 'become something of a ghost town, quietly falling into disrepair in the tropical sun and rain, the jungle steadily reclaiming its own'. Australian military government remained, but with a decidedly unimpressive physical presence.

The people of the Admiralties saw first the Germans, then the Australians, the Japanese, and-once more-the Australians take control of their islands and, they supposed, their destinies. In the 1950s, however, Admiralties people tended to credit America with returning Australia to power and to regard the Americans as a superior people. The mass of men and materials the American invasion brought to Manus at remarkable speed was unlike anything the islanders had ever experienced. If any aspect of their relations with the Americans had been unpleasant, they appeared to have forgotten it.

Lamont Lindstrom and Geoffrey White document that in the Pacific Islands as a whole, indigenous people-'save for those who suffered the most' in the fighting - viewed Allied troops favourably in comparison with prewar colonials (1989: 12ff.). In Manus, the Americans paid the

12 By the end of the war, more than 3,500 Melanesians had served in Allied combat battalions (Nelson 1980: 19, cited in Lindstrom and White 1989: 31). 
local people who worked for them well by Territory standards. Islanders often told members of the Mead party that the Americans had also been friendly - they let them ride in American vehicles and patrol torpedo boats and the Americans enjoyed fishing from the locals' canoes. And they had been generous, giving abundantly of their food, clothing, and other supplies. Even years later, Admiralties life was full of American army surplus. Many people wore parts of American military uniforms. To many of the people of Manus, their relationship with the Americans seemed to have dimmed the lines that separated colonial masta, the colonial term of address for male whites in Tok Pisin, from native boi, the colonial Tok Pisin term for male indigenes, regardless of their age.

Although while colonials often used the term 'native' in a highly pejorative sense, indigenous New Guineans in this era used its Tok Pisin cognatenetiv - to speak of themselves without negative connotations. It appears frequently in Manus people's Tok Pisin speech of the time. We will sometimes use it interchangeably with such terms as New Guineans, indigenous people, indigenes, and local people. At least by the current millennium, some younger indigenous Manus people had taken to calling themselves Manusians, although this is still a minority usage.

Manus accounts of their experiences of the war also emphasised the presence of black Americans in the construction battalions. To travel by sea from Pere to Lorengau, one still passes under a bridge connecting the main island (the Great Admiralty) and Los Negros. While passing under the bridge by canoe in 1954, a crewman proudly pointed it out to Schwartz, saying: 'Do you know that this bridge and that road were built entirely by black American soldiers?' In their pride that people with whom they identified had mastered this most impressive part of American culture, many people ignored or failed to notice that black American soldiers were doing most of the military's manual labour. What they saw instead was a clear sign that they, too, could accomplish such feats. This accords with what Lindstrom and White report of the Pacific theatre of war as a whole-that 'it was not the physical segregation of the U.S. forces that made an impression on island memories but their "similarity of condition" [of black and white troops] in terms of styles of dress, food, and work. The obvious abilities and achievements of American blacks personified the prewar aspirations of many Islanders' (1989: 18; cf. Robinson 1981: 161). 
We must recognise that Neville K. Robinson (1981: 173) reports contrary perceptions of the relationships between Pacific Islanders and black Americans, and Lindstrom and White report numerous accounts of 'islanders' wariness and fear of black soldiers' (1989: 18). Even so, the evidence is strong that on Manus, in the flood of materials pouring from the cargo ships and the works of the black soldiers, islanders saw a new way of life in which —as they put it in Tok Pisin—life was set stret - that is, straight or as it should be. People lived in brotherhood and solidarity and, working in harmony, accomplished great things.

What people saw of white life during the war was, of course, smooth cooperation enforced by a steeply hierarchical military regime, not everyday life in white societies. Indeed, much of white life in colonial New Guinea took place within institutions-government, the colonial police, missions, plantations - that put a premium on hierarchical order and obedience. Smith (1994) has pointed out how, elsewhere in New Guinea, indigenous people assumed that whites were spontaneously more cooperative than New Guineans. He argues, however, that they did so because they knew little or nothing of the rigid discipline that enforced order in the white institutions with which they were familiar. But these perceptions in turn reinforced a conviction with deep indigenous roots that material wealth — that is, shared material wealth — was itself evidence of underlying social harmony (cf. Brison 1991; Errington 1974).

Such an analysis may well apply to Admiralties perceptions of American society and American wealth after the war. There is no doubt, however, that Manus people wanted fuller participation in the obviously superior knowledge, wealth, and power the Americans displayed. This new way of life had seemed within reach for a short time. But it disappeared as suddenly as it had arrived, leaving many wondering how they could come fully 'inside' (in Tok Pisin, insait) this new world — that is, how they could become privy to the knowledge underpinning it.

\section{A home-grown impetus to change: The dark side of non-commercial exchange}

Paliau would eventually give people a way to act on that grand frustration. But he was not the only grassroots activist to emerge in Manus in that era. Repeatedly seeing their elders appropriate the rewards of their wage labour to feed into the system of affinal exchange pushed a number 
of young men to challenge that system. We will tell some of their stories below. It is important to keep in mind that these iconoclasts were acting on discontent inherent in the indigenous system, their imaginations stimulated by exposure to hitherto unknown options. Their ambitions were more modest than those of the Paliau Movement, and this, in addition to their lack of Paliau's talent for organising, helps account for their limited success.

Mead's broad description-in both Growing Up in New Guinea and New Lives for Old —of the affinal exchange system ('an economic treadmill') depicted the indigenous system when it was already under pressure to change. But it rings true, especially in tandem with Reo Fortune's 1928 case studies, presented in Manus Religion, of divining causes of illness and misfortune in Pere village. A large part of the bad behaviour for which the ghosts were prone to punish the living concerned failing to meet affinal exchange obligations; for example, failing to provide food or dogs' tooth valuables for an exchange organised by someone who had provided for one of your endeavours; failing to support your kin in mounting exchanges or repaying their exchange debts; fecklessly consuming pigs, fish, or sago you could contribute to an affinal exchange; stealing goods destined for an exchange; or upsetting elaborate arrangements for affinal exchange by dallying with someone else's spouse or prospective spouse and upsetting an existing or planned marriage. Not participating in the system was almost inconceivable. It meant forgoing your prospects for status, respect, and marriage and family. In colonial Manus, then, even being able to imagine opting out by depending on wage labour or exploiting new opportunities in the emerging money economy probably increased longstanding tensions over the ways people could deploy their labour and wealth.

Following Marcel Mauss (1967 [1925]), anthropologists often call the general form of distributing goods that is dominant in indigenous Manus society 'gift exchange'. They distinguish gift economies from economies in which goods circulate via the exchange of commodities (that is, things that can be bought and sold without entailing further relations between the buyer and seller). They emphasise, however, that the commodity economy versus gift economy distinction is relative, not absolute (cf. Smith 1994: 10). That aside, in a hypothetical pure commodity economy, material goods circulate only through impersonal sale and purchase. People seek material gain rather than enduring personal relationships between the parties involved. In a hypothetical pure gift 
economy, in the words of C.A. Gregory (1982: 19), 'what a gift transactor desires is the personal relationship that the exchange of gifts creates, and not the things themselves'.

Formal occasions for giving and receiving in gift economies include births, marriages, deaths, initiation rituals, dispute settlements, and the grand-scale, long-duration cycles of gift giving for which Papua New Guinea (PNG) is famous: the Kula of the Trobriand Islands, described in Bronislaw Malinowski's Argonauts of the Western Pacific (1922), and moka in the Mt Hagen area, described by Andrew Strathern in The Rope of Moka (1971), are two examples. But a great many things-primarily food-circulate in less formal, daily, non-commercial giving and receiving among kin. Also, where gift exchange predominates, people usually do not work for others in exchange for immediate payment of any kind; rather, they work to fulfil social obligations.

The connotations of the word gift, however, make it easy to romanticise such a way of distributing material things and allocating labour. Paul Sillitoe (1998: 84-5) wisely suggests using the term sociopolitical exchange, which emphasises that the circulation of goods is governed not by market incentives but by social and political concerns and according to shared understandings about who should give what to whom and when. Sociopolitical exchange is central to societies throughout Melanesia. Some anthropologists argue that giving and receiving food in a sociopolitical exchange system not only reinforces bonds of mutual obligation, it creates deeper bonds. For instance, Melanesians may feel that food produced on ancestral land or using magic bequeathed by the ancestors is permeated by the spirits of these ancestors. Thus, as Bruce Knauft (1999: 47) puts it, a gift of food is 'a gift of oneself in a fundamental way'. Similarly, many anthropologists argue that giving and receiving food inclines Melanesians to experience themselves as embodying relationships among many people rather than as self-contained individuals. ${ }^{13}$

But as redolent of warm mutuality as such characterisations may be (although not necessarily intentionally), life in systems of sociopolitical exchange can be at least as fraught with troubles as life in a society where isolated individuals bear alone the stresses of impersonal buying and selling in unpredictable markets. As Mauss emphasised, the gifts in gift

13 Marilyn Strathern (1988) makes what is probably the best-known argument along these lines, an argument that remains highly influential. 
economies are not voluntary, they are obligatory. Further, the personal relationships gift exchange creates or perpetuates are not necessarily pleasant. Mead and Fortune used the language of commerce-words like debt and credit— to describe Manus affinal exchange. But they recognised that the affinal exchanges on which indigenous Manus life pivoted were sociopolitical. ${ }^{14}$ The parties relinquished the goods they received via other exchanges, gaining no permanent material advantage. ${ }^{15}$ They did so to create or maintain personal relationships. But these were not relationships of trust and equality. Rather, they were relationships of obligation and invidious comparison. Participants in affinal exchange could gain prestige, but they could also lose it. They could earn greater respect, but they could also become objects of scorn.

As we said in Chapter 3, Leavitt (2004: 183-4) points out how today's Papua New Guineans can find life in a world in which one is defined by one's exchange relations burdensome. Ethnographic data suggest that discontent within sociopolitical exchange systems in Melanesia and other world regions probably predates contact with commercial societies. Biersack (2017) observes that, not only in Melanesia, but in other parts of the world where people often attribute death and misfortune to witchcraft or sorcery (that is, where they personify the causes of such events), they are also prone to assume that such malevolence is retaliation for failure to meet obligations to give of one's wealth to kin. Witchcraft, wherever people fear it, Biersack (2017: 296) observes, is the 'dark side' of exchange (cf. Smith 1994: 173-6). ${ }^{16}$

14 They did not, however, use this term.

15 Mead and Fortune tell us less about the trade through which people accumulated some of the goods for affinal exchange. We know that people did not use modern money in transactions, but it is also likely that transactions were not the same as bartering, either. Carrier and Carrier (1989: 155) describe what they could surmise about precolonial trade on the north coast of Manus Island from their research conducted in the 1970s: 'Trade partners should not have had a purely businesslike relationship, but instead were expected to give gifts openly and generously without haggling. It was expected that they would give small gifts to each other when they met, that they would make special visits to each other's villages occasionally to make large gifts or to participate in formal exchanges, and that they would be able to call on one another for help in collecting foodstuffs or other goods for formal exchanges or special projects such as house- or canoe-building'. Ian Hogbin (1935: 401) described participants' expectations in a trading system on the north coast of mainland New Guinea, as he observed it in the 1930s, in a similar way. He noted as well that 'if a man hands over a parcel of nuts and requests that he be given tobacco he definitely expects a bundle of a certain size ... if he considers the return gift inadequate he has no direct redress, but in the future he will avoid this particular [trading partner]'.

16 The other chapters of Pentecostalism and Witchcraft (Rio et al. 2017) in which Biersack (2017) appears are worth consulting on this issue. Of the several additional works Biersack cites, Bercovitch (1994) is of particular interest. 
The situation Schwartz observed in 1950s Manus was an instance of tension in a sociopolitical exchange system aggravated by contact with a commercial or commodity system. C.D. Rowley (1965: 110-11) argued that this state of affairs was causing friction between generations in many parts of the Territory. And Smith (2002: 48) observes that 'ever-increasing tension between the possibilities [people] see in the money economy and the pull of familiar forms of social and economic relations based on kinship and noncommercial exchange' persists in PNG today. It is a tension that is 'at the heart of cultural contestation' (Knauft 1996: 214) in contemporary Melanesia in general (cf. Smith 1994: 174-6; 2002: 48, 149).

\section{Emerging local resistance to the traditional order: Some cases}

Even the earliest exposure to the radically different European way of life may well have exacerbated Manus discontent with affinal exchange. After the war, many of the younger men-particularly those disposed to become leaders - found it hard to endure the fact that the old course of native life, separate and inferior to that of the whites, should return. For the people who were to comprise the Paliau Movement, life could never be the same again. They were not sure what would happen, but it was almost unimaginable that things would not change and change radically. Many of those who had been caught by the war in such distant Territory towns as Rabaul, Finschhafen, Talasea, or Lae, returned to their villages wondering what they might do to make their homes more fitting places for their altered selves.

Schwartz met the leaders of seven attempts other than Paliau's to formulate a new way of life, more satisfactory in itself and better integrated with the outside world than the ways of indigenous ancestors or the amalgam of old and new that was life before the war. Some of these attempts began before the Japanese invasion and had to be abandoned when the war broke out, but most reappeared with the peace. The innovators of whom we speak below confined their ambitions to their own villages or small groups of related villages. Although some spoke of a blanket repudiation of the past, most focused on specific practices or institutions, in particular the system of wealth production and exchange- that is, the affinal exchange system-dominated by the older men. This was not only burdensome in all the familiar ways; it stymied ambitions to take advantage of the new opportunities available in the postwar world. 
Perhaps the most significant similarity among these attempts at innovation was their failure to recruit and sustain a broad base of adherents. It is important, however, to see the Paliau Movement in the context of the intensifying interest in social innovation of which these efforts are evidence. We will also meet the leaders of these efforts again in later chapters, for they all became important figures in the Paliau Movement.

\section{Napo of Mbukei}

Napo's attempt at transforming life in his own village is one of the earliest known in the southern Admiralties. Napo was from the village of Mbukei, the westernmost of the Titan-speaking villages. German planters had taken over the Mbukei chain of islands to create a coconut plantation. Mbukei people, however, continued to build their houses over the water and take their living from the sea, the reef, and the lagoon. Like most of the leaders of the Paliau Movement, Napo left the village in his early teens to work for whites, spending five years employed by a trading company, then joining the colonial police force. In about 1937, after three years serving with the police in mainland New Guinea, he returned to his village on leave. He was then, he estimated, about 23 years old. He did not want to return to the old routine, to years of indebtedness to the older men who would provide him with the wealth with which to obtain a wife and, that debt paid, to an endless round of work to amass wealth to achieve his own status.

Like other young men, Napo wanted eventually to return to his village, to marry, and to make a life there. But if he, a changed man, wanted a life into which he fitted, he would have to remake the world of his village. He wanted to terminate the unbroken lines of obligation and striving for status that came down from the past, but which offered his generation no satisfaction. He offered his age mates an iconoclastic attack on the keystone of the old system, calling for eliminating the great exchanges of wealth connected with marriage. Like the other people of Mbukei, he was a Christian and claimed that he had little fear of the ghosts who sanctioned failures to meet the heavy exchange obligations around which so much of the old culture orbited. But he still faced the opposition of older generations. They had already acceded to Catholic Mission demands to abandon such customs as polygamy, and they wished to retain as much as possible of what remained. According to Napo, although he saw his 
proposed reforms as modelled on white life, the local Catholic missionary, who was white, opposed him for what, in Napo's telling (below) sound like purely racist reasons.

When Napo's first efforts to recruit supporters for his plans proved unsuccessful, he left the village to serve another term in the police force in the Middle Sepik area of mainland New Guinea. Here, he said, he found scope for his abilities. He served his apprenticeship working with the Australian patrol officers who maintained superficial supervision of the area, and he learned the workings of colonial law from participating in government courts. Eventually, he was placed in charge of an outlying station for a year, responsible for keeping the peace and promoting and maintaining administration policies. It was clear in his telling that he was proud of his accomplishment, but he also continued to think of what he could do when he returned home, which had always been his plan. When Napo came back to Mbukei in 1940, he attempted again to lead his village into a new life. Again he addressed himself to the young men, this time denigrating the entire indigenous culture. He concentrated, however, on the economic activities that centred on marriage exchanges and he advocated abandoning native valuables — such as dogs' teeth and shell beads-in favour of Australian currency. As he recalled it in conversation with Schwartz, this was the essence of his message:

Our traditional way of life is no good. All of the ways we act trouble our minds so that we don't think straight about God. Everything we do ruins us. We are always in anger. It would be better if we changed the way of our ancestors and made a new one of our own. Why is it that all of the white men have stores, but you and I are unable to take a dog's tooth or anything that we have to give to the store and get something?

Again the older men opposed him. The luluaicomplained to the missionary and to the paramount luluai of the south coast of Manus (Kisekup of Bunai village). It is impossible now to know the actual attitude of the Catholic Mission, but Napo described it thus:

The Father heard about it and he was angry at me. He forbade me to go to church. He wasn't angry at me because I had any idea of changing the talk of the mission. 'No', he said, 'You are no masta, you are no white man. You are incapable of acquiring all that belongs to us white skins. You must confine yourselves only to the ways of the black man'. All the men in the village said that the Father told them this. But I said, 'Never mind. He is a white man and I am a native. I will do as I wish with my own village'. 
Despite such opposition, Napo gained a following among the younger men. The mission, once satisfied that he was not attempting to interfere with its work, permitted him to receive communion again. The outbreak of the war, however, rendered all other concerns secondary. Nonetheless, Napo said that by the end of the war he had convinced the older men to promise that they would set a date for the termination of the affinal exchange system. But this was a highly qualified promise, because they held that villagers first had to meet as many of the obligations of the old system as possible; they still had to make the last big feast.

This was a limited victory, but by then there was excited talk of change all over the Admiralties. Napo was hearing of other men trying to introduce similar programs elsewhere. Although he was not sure exactly what it was, he told his followers that something of great importance was about to happen, and he saw that they were eager for it. Napo no longer saw his work as a purely local movement, depending solely on local ideas and initiative. But he was still looking for a plan of action that would move his village quickly and radically out of the past. For help and inspiration he sought out other innovators of whom he had heard. First he contacted Bonyalo of Pere. Later, he would hear news of Paliau.

\section{Bonyalo of Pere ${ }^{17}$}

In 1928, Mead and Fortune stopped in Rabaul, New Britain, on the way to Manus, to prepare for the next stage of their journey and to decide in which village they would conduct their research. Such decisions often turn on small things. In this case, they selected Pere partly because they found a student from Pere in the government school at Rabaul who knew enough English to act as an interpreter until they could get some grasp of the Titan language. Opportunities for formal schooling were rare in those days, but not particularly coveted among the Titan, many of whom preferred their young men to stay at home and work for their elders. Mead (2001 [1930]: 82) speculated that when government representatives visited Manus seeking young men to study in Rabaul, Bonyalo had been allowed to go because he was fatherless and thus more expendable than the son of an ambitious man. Whatever the case, immediately after the war it was Bonyalo who led Pere in its first movement towards a new culture.

17 Mead mentions Bonyalo in Growing Up in New Guinea (2001 [1930]) and New Lives for Old (2001 [1956]), in both of which she spells his name Banyolo. 
In 1929, after working for Mead and Fortune, Bonyalo returned to school in Rabaul. He stayed away from Manus for most of the next 25 years. Among other jobs, just before World War II he worked as a clerk in a government store in New Britain, where one of his duties was issuing rations to the colonial police. While doing so he met Paliau, who was then a sergeant major in the force, the highest rank an indigenous man could reach. Bonyalo told Schwartz, however, that he and Paliau did not discuss plans for remaking the Manus world. Unlike most of the other early local advocates of change, Bonyalo claimed that for most of his years away from home he did not think about ways to change his village.

During the war Bonyalo worked — under duress—-for the Japanese, along with hundreds of other Admiralty Islanders held in New Britain. After the war, he worked for ANGAU briefly and then returned to Pere in 1945. The intense fighting of the American invasion took place mostly towards the eastern end of the main island and did not extend to Pere's vicinity. Villagers had earned cash working on the American military bases, and they were using it in affinal exchanges, hanging American dollars alongside Australian shillings and the traditional dogs' teeth and shell beads in the displays of wealth. The village must also have been full of the material goods acquired from the Americans as gifts, payments for food or work, or from among their discards. These included tools, galvanised iron, electrical cable, metal airfield surfacing panels, lumber, army cots, lockers, blankets, mattresses, chairs, kitchen utensils, and clothing. ${ }^{18}$ Villagers were wealthier than ever, but their aspirations had grown even more. In comparison with what they had seen of the American way of life, they were poverty stricken. For Bonyalo, who had spent more than half of his life in colonial towns, the village seemed too much like the village he had left so many years before.

Now in his mid-thirties, Bonyalo immediately began trying to move Pere towards a clean break with its past. But he began with an act reminiscent of the past. He killed a large sea turtle and called the young men of the village to a feast. At first he ignored the older men, whom he expected would resist. He hoped that he could gradually persuade them to discard the old culture, but Bonyalo was cautious. He avoided speaking of

18 Much of this probably wasn't visible at first glance. In 1953, Schwartz and Shargo noticed how much such goods had infiltrated village life only through mingling with Pere people at their work and in their homes. But photographs of Pere village exteriors taken by members of the American armed forces around the time of Bonyalo's return to Pere show almost no evidence of change in the material style of life in comparison with 1928, as seen in Fortune's photos. 
matters pertaining to either the still-important household ghosts or to Catholicism. And to avoid trouble with the government, he kept a book in which he recorded the content of his meetings. The older men opposed him, as anticipated, but Bonyalo and his adherents persevered, going by canoe at night to a nearby uninhabited island where they met in secret.

When Napo visited, hoping to learn of a program more effective than his own, he was disappointed. Bonyalo's program was essentially the same as the one Napo had offered in Mbukei. Bonyalo called for standardising the obligation of the groom's side in affinal exchange at $£ 10$ Australian currency. This was to be a single cash payment, without reciprocal gifts of foodstuffs on the part of the bride's family. Bonyalo also advocated doing away with other feasts and exchanges related to marriage. There were to be no more metcha payments, for instance-what Mead (2001 [1930]: 61-4) called 'the silver wedding payment which a rich and successful man makes for a wife to whom he has been married fifteen or twenty years'. The payment a husband made to his wife's family in return for the care she received in her confinement, the pwaro, was also to be restricted. A wife's kin cared for her until 10 days after she had given birth, at which time the husband made the pwaro payment. Bonyalo declared that a woman should give birth in her husband's house under the care of two or three of her own female relatives. The husband's obligation would be met by a small cash payment to each of these women, who were to return to their homes 10 days after childbirth.

These would have been revolutionary changes, radically limiting the ability of the old to dominate the young. A young man, regardless of the status or wealth of his father, could earn through wage labour the cash he needed for the initial payment to the bride's family and for the pwaro. He would no longer be obligated to many years of service to the man who financed his marriage with large loans of dogs' teeth and shell money. The changes in postnatal care Bonyalo advocated would also have increased the privacy and autonomy of each household.

His elders may have considered the above elements of Bonyalo's program the most incendiary. His call for ending child betrothal must also have raised hackles, as would have his proposals that young men and women were to marry according to their own preferences and that premarital sexual relations should be permitted. He also proposed periodic village meetings to make decisions on community affairs and greater concentration on 
working for money. Since the village offered virtually no opportunities for earning money, the latter meant that more men would be going away to work.

Bonyalo told Schwartz that an ANGAU patrol officer who visited Pere encouraged him. The patrol officer read Bonyalo's record book with approval, but warned him to confine his activities to his own village. Other villages could copy his example if they wished, but Bonyalo was not to propagate his ideas beyond the village. According to Bonyalo, the ANGAU officer told him that if he and his followers continued their efforts to organise along the new lines and continued their meetings, the government would let them participate in a Native Government Council, an elected body that would give them a limited form of local participation in territorial government.

Bonyalo made a bold beginning, but his efforts in Pere soon collapsed. The prestigious older men continued to pull the younger men into the affairs of the old culture. John Kilepak, an articulate man of high status who might have been able to draw others of his station into a new system, made a large payment to obtain a wife for his young kinsman Karol Matawai in the neighbouring village of Patusi. ${ }^{19}$ Pokanau, a former luluai of Pere, supported continuing the old marriage system, encouraged by Kisekup of Bunai, who-as paramount luluai for the south coast of Manus-had helped suppress Napo's activities in Mbukei before the war.

In the neighbouring village of Bunai, Samol was promoting changes similar to those Bonyalo was promoting in Pere. He joined Bonyalo in complaining to the Australian administration about the adamant support of the luluai for large exchanges of wealth between the families of bride and groom. Many colonial officers opposed the system of affinal exchange because they understood it incorrectly as bride purchase. So, Samol and Bonyalo were able to convince administration officers to tell Kisekup and Pokanau to withdraw their opposition if they wanted to keep their appointed positions.

19 Kilepak, like Bonyalo, had also worked for Mead and Fortune as an adolescent in 1928. He later became one of Schwartz's most valued collaborators. During Schwartz's travels throughout the Admiralty Islands in the 1960s, Kilepak often captained Schwartz's canoe crew. His work with Mead and Schwartz led to several visits to the United States in the 1970s. 
This, however, didn't affect Kilepak's plans to provide the valuables Karol Matawai needed to marry. Since the intended bride was from Patusi village, which had no part in the struggling Pere reforms, Kilepak had little choice but to meet these demands. Bonyalo then insisted that Kilepak make the payment of durable valuables but refuse the return gift of foodstuffs from the bride's relatives. Such a move would have been almost as effective a blow against the old system as refusing to provide the groom-side payments. The system depended on reciprocal exchange between the families linked by marriage. The receiving parties rarely kept the payments. Rather, they passed on what they received to meet exchange obligations to others. It was impossible to step out of this continuing flow of wealth without sacrificing one's status among all those involved in the never-ending cycle.

Bonyalo's insistence that Kilepak could pay but not receive anything in return was also a part of his proposed approach to sexual morality, which held that licit sexual relations required some kind of payment to the woman. He argued that if Kilepak gave durable wealth and accepted a return gift, they cancelled each other out and it was tantamount to getting the bride for nothing (a position that administration officials might have seen as confirming their view of the system, had they known of it). That would entitle the bride's relatives to demand further payment in the future, and the old cycle of payment and repayment from which the young men sought to escape would continue.

When one of Bonyalo's own adherents made a pwaro feast to help his aged mother meet this traditional obligation, Bonyalo felt he had failed. There was no possibility of a real break with the past as long as the younger men lived with their elders, to whom they were obligated, and who jeered and taunted them when they failed to meet those obligations. At about this time, he heard that Samol's movement in Bunai (described below) was encountering similar obstacles. This had prompted Samol to recruit a group of young men from Bunai to move to land to which he had rights at a place called Lompwa, not far along the coast from Bunai. Samol and his followers built a new settlement there for those who wanted to follow his program.

Bonyalo had no land at his disposal. Among his young followers, however, was Makis, the son of a Solomon Island native who had come to the Admiralties as an indentured plantation labourer and who had settled there permanently. Makis told the Australian manager of a plantation on Ndropwa, one of two small islands about three miles offshore from Pere, 
about Bonyalo's dilemma. The manager invited Bonyalo to bring his men to Ndropwa where they could live and work as wage labourers, gathering coconuts and curing the meat to make copra. Bonyalo agreed, feeling fortunate to have the support of friendly Europeans.

By this time, Paliau had returned to Baluan from Rabaul, where he had remained for some time after the war (see Chapter 5), and hearing of Bonyalo's plan he came to see him in Pere. As Bonyalo recalls the visit:

He [Paliau] spoke to me now. 'I have heard that you want to go to Ndropwa so I came'. I [Bonyalo] said, 'Yes, I am tired of the village'. Then he said: 'You can't tire. It is your village. You have to be strong about it. There is no one else who will make your village for you. Only you can do it'. He said: 'I didn't come to persuade you. I came to hear what you have to say. When I was still in Rabaul I heard of you. Everyone said that you were strong for this idea here'. Then he said: 'That is good. I have come to help you. You and I will work together. It is a good idea to hold meetings in the village and to let the government know about them. If you do something in secret there will be trouble. If you like, I can help by giving you some ideas. Now forget about Ndropwa. Let it go. Now you and I can talk here first, then in two or three days I will go back to Lipan [Lipan village, on Baluan]. We are making a meeting house on Baluan. We will open it on Friday. This is not a matter of persuading people. A man can come if he wants to'. Then I [Bonyalo] told him I was just going to work here and there for a while. I said: 'You do it in your own village. They will all see. Let them observe; then, if they want to do the same in my village. I will help them later'.

Bonyalo thought that removing enough young men from the village would help persuade the elders to accept his proposals for fundamental changes. Despite Paliau's advice, soon after his visit Bonyalo went to Ndropwa with young men from Pere and Patusi. According to Bonyalo, his followers included the most important and most intelligent of the young men of these two villages. Without them, he reasoned, the older men of Pere could not continue the ceremonial and economic activities of the past. Bonyalo's plan might have succeeded. Samol even told the plantation manager that he might bring his followers from Lompwa to join Bonyalo on Ndropwa. But before Bonyalo's men had collected their first month's wages, the Noise reached the south coast (as described in Chapter 6), disrupting this and all other local revolts against established village authority. 


\section{Samol of Bunai}

Samol was of the same generation as Napo and Bonyalo. He also had left his village in adolescence to work for the whites. Unlike Napo and Bonyalo, he did not leave Manus but worked for about 10 years as a clerk in a store in Lorengau. From Lorengau he returned frequently to Bunai, which was only one day's travel by canoe. Samol learned to read and write Tok Pisin from other indigenous workers in Lorengau and he learned enough arithmetic to handle Australian currency. He never attended a government or mission school, yet in his late twenties he became a Catholic catechist. As a catechist he faithfully kept a record, in a neat Tok Pisin hand, of the church services he held. Like Napo, he impressed Schwartz as someone of quiet authority and quick intelligence. He belonged to a high-ranking family and Kisekup, the paramount luluai of the south coast, had announced that Samol was to be his successor (although the administration would have had to appoint him as such).

Samol spent the war years on Baluan Island, working as a catechist. Although the missionaries had been evacuated, Samol continued to hold services until the end of the war. After the war, he worked for a short time as a construction labourer at the American base. Like other local people, Samol was tremendously impressed by the American armed forces. One day, for example, as Schwartz and Samol walked along the road to Lorengau from where they had beached their canoe outside town on arriving from Bunai, Samol described in great detail how the Americans had built the first hard-top motor vehicle road in Manus with dynamite and huge earth moving machines. But 15 miles from all this activity, his village was still built on posts over the lagoon, much as it had been when he was born.

Samol's program for change in Bunai was almost identical to those Napo and Bonyalo campaigned for in their villages. A significant difference was that he advocated eliminating all avoidance behaviour between designated classes of kin, customs that profoundly affected relationships between men and women. Mead (2002 [1934]: 52-86) wrote that Manus interpersonal behaviour among kin as she observed it in 1928 fell into three categories: joking relationships, relationships like that between brother and sister marked by affectionate solicitude, and avoidance relationships. From the time of their early betrothal, engaged boys and girls avoided not only one another but also future in-laws of the opposite sex. They were taught to feel shame in the presence of these people. Women even carried a bark cloth 
cape with which to hide their faces in case one of their male relatives by marriage suddenly appeared. In addition to eliminating these avoidance relationships and the accompanying shame, Samol added to Napo's and Bonyalo's programs a call for husbands and wives to eat together, talk together, and walk together, just as he had seen white husbands and wives do. ${ }^{20}$

Samol wanted to remain in Bunai, but when his program for change brought him into conflict with his adopted father and brought his followers into similar conflicts, he moved them to Lompwa. He hoped that decamping with his adherents might bring Kisekup to agree to try his ideas for a new kind of society. Beyond that, his plans were vague. He hoped that he and his followers could find some means of making money and he began building houses at Lompwa. When the Noise came to Bunai, Samol and his group in Lompwa did not feel its early impact, but its effect in Bunai ruined his chances for pursuing his own plans for change there.

\section{Lukas of Mok}

Lukas must have been about 30 years old when he returned to the Admiralty Islands after the war. He had worked for a few years before the war as a mechanic at Vunapope, the Catholic Mission headquarters near Rabaul. Later he joined the crew of a small boat owned by an Australian and based at Rabaul. When the Japanese invaded, Lukas was with a group of other men from the Admiralties at Talasea in New Britain and he volunteered to help the remaining Australian troops in New Britain escape safely. His experiences won him a Loyal Service Medal and, Schwartz recalls, the respect of the Australians who knew him.

While Lukas was with the other Admiralties men at Talasea, the Lakalai and Kombe people of that area were in the throes of a cargo cult. Lukas said he thought these natives were 'crazy'. According to Lukas, the Lakalai, led by Batari of Kamalakese, took the Catholic missionary prisoner, smoked him briefly as if they were producing copra (to produce copra, coconut meat is smoked over a slow-burning fire; this is a detail that may be apocryphal), and later turned him over to the Japanese. According to

20 Although advocates of doing away with these restrictions had been exposed to Catholicism, it appears that they acted without mission prompting. Similarly, when native Hawaiian rulers abolished the kapu (taboo) system in 1819 there had been substantial European influence in Hawai' $\mathrm{i}$ for decades, but the European example was only one factor among many (Tanabe 2005). 
Lukas, the Kombe, whose cult leader had proclaimed himself king, also expelled a Catholic priest from his island mission station. This missionary and another, fearing the anti-mission feelings of the cult followers, engaged Lukas and another Admiralties man to guard them. The arrival of the Japanese saved the missionaries from the cargo cult, but doubtless not as they would have wished.

The Japanese sent Lukas to Rabaul, where he worked as a labourer. Lukas told Schwartz that he thought a good deal about the indigenous way of life during his months in Rabaul, alternating working for the Japanese and hiding from the American bombing. He summed up his thinking as follows:

The thoughts that I found went like this. God made all of the men on earth. But as far as the condition of the natives, I don't think that this was so. Why is it? All white men, they are men. They have two hands and two legs. We also have the same. What is it with us natives? They can fly in aeroplanes and sail on the sea in ships while we stay just as we are. Now these thoughts were always within me.

Lukas and nine others were able to surreptitiously build a canoe and escape from Rabaul, sailing down the coast to Nakanai and Karua where they found American and Australian troops. Lukas worked with them for a while, before they sent him first to Finschhafen, on the mainland, and, in 1944, from there back to Manus. When he returned to his village, Mok, a Titan-speaking village built over the water adjacent to the small island of Mok, just offshore from Baluan, he tried to put into effect the ideas that he had been formulating during his long absence. Like Bonyalo, Lukas met Paliau in Rabaul, where he too was trapped by the war and under Japanese authority. The Japanese had placed Paliau in charge of the local labourers they had commandeered, but Lukas did not recount to Schwartz any conversations the two of them might have had about revolutionising life when they returned home.

Back in Mok, Lukas called the village men to meetings, omitting the older men whom he believed would summarily reject calls to abandon the ways of the past. He told the younger men that the old ways were like a killing poison. As an alternative to leaving the village, he laid down a series of rules to follow in their relations with their elders. Following these rules, he argued, would bring about change. This is how he described to Schwartz what he told the young men of Mok: 
If your father wants you to go look for food, you ask him what the food is for. If he says it is for a ceremonial exchange, you can't go with him. If he says it is for eating, all right, you can go help him find food. The meaning of my talk is as follows. You know, you of this village, we have no land. We work too hard to find food. We range from the Great Admiralty to Rambutjo. Our bodies are weary from all this work. When we carry food to the village, it isn't used properly as food, it goes for making ceremonial exchange. Our food supply is exhausted too quickly, then hard work finds us again. All this work is what makes you and me die. Now we have to rid ourselves of all this. Where is the mark of all this work? It leaves no mark, not the slightest. It is like this. If you can't comprehend it with your minds, you can see it with your two eyes. Look at Ndropwa. It is like all the plantations. The white man did not make them. The white man's work is only telling us to do the cutting. He says, 'You and I will cut the bush. You and I will clear it and plant coconuts'. Now our work is cutting the bush and planting the coconuts. He just sits down. He doesn't do it. Now why is it that you and I can't make something for ourselves? With everything it is the same. Things don't just appear for the white man. If we did not exist, if we didn't produce coconuts or work copra, where would his cargo come from? Or his store, what could he put in it? I think he could do nothing. It is our hard work that does it. Now today, why can't we do this on our own ground in the same way?

His speech, as he recalled it for Schwartz, went on in this vein, urging the young men of his village to work for their own benefit, to do the same work for themselves that they did for the white men, and to end the fruitless waste of their labour in the endless round of ceremonial exchange. The young men whom he harangued told their fathers of Lukas's program. Their fathers answered that Lukas was nobody. Who was he to talk of abolishing the past? He was not of a high-ranking family. When Lukas again called a meeting, few of the young men came.

Lukas stayed in the village, but shunned all the traditional exchange ceremonies. He had failed, but he was determined to find a way to move people towards a new way of life. In desperation, Lukas called those young men who were still interested to a secret meeting on a small islet near the village. He proposed running away to America on an American warship. They would go up to one in their canoe, ask to come aboard, and then 
plead to be taken to America. He set out with nine other young Moks. But older men took to their own canoes and pursued them, catching them and bringing them back before they reached the American naval base.

Later, Lukas heard of Bonyalo's activities in Pere. He went to Pere to see if Bonyalo had what he was looking for, a substitute for the past and for the past-in-the-present. Lukas's criticism of Bonyalo's plan casts light on why his and other local movements failed. He recalled the conversation as follows:

I went to Bonyalo and asked, 'What are these meetings of yours? I want to hear'. When he [Bonyalo] spoke, it was not like something firmly rooted in the ground, it was like something that just floated. That was the essence of it. I didn't believe in his talk. First he said that he wanted to send all the young men to work copra on Mbukei Island. Then I asked, 'When you are through working copra, then what will you do?' 'Then I will send it to the plantation manager on Ndropwa'. 'Then what will you do?' Then he said, 'If we get a lot of money I want to make a store'. Then I answered: 'True, your idea is all right, but it is like a tree that has neither branches nor roots. You work only on the middle. You think about it'.

In this manner Lukas told Bonyalo that there was nothing really new in the plan he offered and that he had not defined its ultimate goals. Working for Europeans, he told him, left people with few tangible benefits after they'd spent their cash. He went on to tell Bonyalo that the idea of the store was naive and that the European stores had a government and, ultimately, Europe behind them.

Lukas returned to Mok to try again. He spoke against the old marriage system, arguing that marriages by the old system of infant betrothal followed by a series of exchanges between the contracting families were bad and created lifelong resentment between the coerced husband and wife. In Bunai, Samol also had argued that the system could be altered to produce better marriages, though he had focused on the avoidance behaviour that erected a barrier of shame between husband and wife. Mead's (2001 [1930]: 114, 146-8) observations on Manus marriage in 1928 support Lukas's and Samol's views of the strains in such traditional marriages. But, however Lukas formulated his attack on the past, he could add nothing significant to the fragmentary plans for the future that he, too, rejected as inadequate. 


\section{Lungat of Ndriol}

Ndriol is the easternmost of the Titan-speaking villages. Just after the war it was still built over the water inside the reef adjacent to Rambutjo, one of the larger islands that fringe the Great Admiralty. Under favourable conditions a canoe from Ndriol under sail could reach Bunai, on the south coast of the Great Admiralty, in one day, Baluan in one day, or Mbukei in two. The nearest neighbours were the Matankor villages of Rambutjo.

Lungat demonstrated later that he could be an able leader on the village level (as did Napo, Bonyalo, Samol, and Lukas). But he was unique among the leaders of this period because he claimed that he received his calling and the content of his message in a dream. Lungat was younger than the others, in his early twenties, when he returned to Ndriol after the war. Shortly after the war his two brothers died. Both had been catechists and teachers in the village. Lungat says that he mourned them for a long time and thought of them constantly. The following is his report of his dream. (The Tok Pisin term translated here as 'religion' is lotu. It is a word of Polynesian origin, referring in its original context to metaphysical matters. It entered Tok Pisin via Christian missionaries who brought it to New Guinea from Polynesia and adapted it to the task of proselytising for their respective churches.)

I was asleep and I dreamed. I dreamed about Tomas Sion [my brother]. He was in Heaven. He was holding a flag. He held a flag and he came down in a cloud from the east. He didn't come from Heaven directly, he came from the east. He came straight to me and he spoke to me as follows. 'Lungat, I am talking to you. You see, we, your two brothers, we are dead. Many men of Ndriol have died. They didn't just die [without cause], they died because of religion. This religion of the mission which was brought to Ndriol and shown to us and to all Manus villages as far as Mbukei ... This religion, we haven't gotten it right. We aren't doing it right and it is killing many men in all villages. Ndriol is almost finished now. Now I am talking to you. Tomorrow, you tell our fathers ... they are to get all the men of Ndriol together and tell them to get rid of all the customs of the past, throw them out-all the ways of the past, all the quarrels, all the feasts, all the ceremonial exchanges. You must lose completely the way of our ancestors. When you are clear of it, then you will be all right'. [In the Tok Pisin discourses of the Movement, to be 'all right' (orait) meant to be raised to the wealth, status, and condition of the European world. Thus, people said, 'Jesus made the white man all right', 
or 'The Americans taught the American blacks and made them all right'.] When he came he held a ring and the feather of a bird like the kind they write with, a pen. He took the ring and he said, 'Lungat, this ring belongs to you. Put it on your hand'. Then he took the pen and put it in my hand. Then he made the sign of a cross on my shoulder. Then he said, 'This is the mark of us. It is the mark of all of us who are in Heaven. I have brought these three things that I give to you. This mark belongs to you'. He gave me this feather, this ring, and this cross. Then I awoke.

The other local movements, as reported to Schwartz, did not rest on supernatural revelations. Napo and Bonyalo tried to avoid coming into conflict with the mission and they attacked the old culture with specific criticisms. Samol continued to teach the standard catechism. Lukas said that the old system was killing them because of the ceaseless work that it involved. But Lungat claimed he had received the sanction of Heaven (that is, the Christian Heaven) through the ghost of his brother, a Catholic catechist. To Lungat, the ring, the feather, and the cross were indisputable signs of the validity of his revelation. At the same time, the idea that men were dying because they were not following 'religious' rules was reminiscent of the role of the guardian ghosts of house and village in punishing wrongdoing; it was a sanction quite in tune with longstanding beliefs.

Yet Lungat did not succeed either. He spoke to his elders as directed in the dream but, he told Schwartz, 'Nothing happened. No one responded'. He did not even have the partial successes of the others. As he put it, 'I was not a man of high rank. I was not an important man. I was young, just married, but with no children. I was ashamed to stand up to speak'. But the dream affected him deeply. Like the other early leaders, he travelled from place to place looking for other men with ideas that might succeed. He found nothing until he went to hear Paliau.

\section{An Usiai case: Kampo of Lahan and Pita Tapo}

The five men discussed above were Titan-speaking people from lagoon villages. Schwartz was able to learn of only one significant local effort to foment radical change in the villages in the interior of the Great Admiralty. ${ }^{21}$ Its leader was Kampo, a catechist who also had a long history

21 It is likely that there were other movements among the Usiai and there may well have been some among the Matankor of the north coast. However, Schwartz was able to obtain reliable information only on the Lahan movement and the movements led by south coast Titan described above. 
of work for Europeans. Working as a cook, Kampo had been to New Britain and mainland New Guinea. He spent the war in the Admiralties, working for the Japanese-again, under duress-until the American invasion. After the war he took casual jobs for a while if they allowed him to be near the remaining Americans. Gambling was nothing new in the Admiralties and games of chance using European playing cards were among the first customs borrowed from the whites. In the excitement and comparative prosperity of the immediate postwar period there were some epic gambling sessions that people still spoke of in the 1950s. The Usiai village of Lahan was the scene of some of the largest and Kampo took part for a while. But Kampo's interest in gambling did not last long. $\mathrm{He}$ felt an unusual sense of responsibility for his village and for the Usiai in general. He became the luluai of his village, but this office gave no scope for extending his influence to other Usiai villages.

Kampo possessed all the legitimate authority that a preferred position in the old social structure could give him. He was a lapan and early in life he had given some of the larger feasts needed to validate his rank. He was also literate in Tok Pisin and had the combined sophistication of a Catholic catechist and a man with considerable experience working for Europeans, with whom he had got on well. After the war, his greatest desire was that the Usiai form larger units from their small, scattered villages and make copra plantations of their own. Such a program was more plausible for the Usiai than for any Titan, although not without problems. The Usiai had ample land, only a small part of which they used for gardening, but it would have been hard to clear the dense tropical forest and keep it cleared for the approximately eight years needed for coconut palms to mature. Kampo, however, thought that the effort could provide the means to bring his village to a European living standard.

As luluai and an influential man by traditional standards, he tried to make as many changes as possible in his own village. He pushed people to build their houses off the ground, on posts, imitating in this both the Europeans living in Manus and the Titan. He encouraged them to build tables and chairs and buy the few essentials of European clothing that they could afford. Some older villagers opposed him, but his leadership rested on a firm foundation and his ideas could not be dismissed lightly. In spite of a promising beginning, however, he was dissatisfied. 
He decided to send for Pita Tapo, ${ }^{22}$ an Usiai who at the time was working for ANGAU, which still administered the Territory. Tapo was reputed to be intelligent and to know a great deal about the ways of the whites, whom he had come to know while working as a domestic servant. Then the war had trapped him in New Ireland, where he had worked-without choice-for the Japanese. The Japanese recognised his ability and sent him to school. The war ended before he could learn to speak more than token Japanese, but the other students taught him to read and write Tok Pisin. Tapo answered Kampo's summons and returned to Manus. Collaborating with Kampo, he went from one village to another on what had come to be called the 'Number Two Road' (in Tok Pisin, Nambatu Rot) in the interior. This was one of a few bush trails created or improved by the German colonial administration in the late nineteenth century. In the 1950s, the Nambatu Rot connected interior villages relatively close to the south coast, among which were those most involved in the Paliau Movement. ${ }^{23}$

Tapo sought to bring together in a single place a group of widely scattered villages sharing a common dialect. He found that most of the young men were absent, scattered among the various European centres, working. Few villagers he met felt there was any real possibility of living like Europeans. They wanted to have some of the things Europeans had, and to live as-in their vague conceptions-Europeans lived. But most were apathetic, for they could imagine no way of achieving this.

The people of a number of other Usiai villages regarded those of Lahan as too eager to be like Europeans and, Schwartz was told, sometimes ridiculed them as 'white men'. Kampo and his young followers, however, seemed to take pride in distinguishing themselves from what many of them regarded as the backward villages deeper in the interior. But Lahan - a settlement of no more than 90 men, women, and children — could not stand on its own. It was linked to other Usiai villages through intermarriage, which entailed, as it did for the Titan, obligations to conduct years-long series of feasts and ceremonial exchanges. Bulihan village had long tended to

22 By this time, many Manus people had acquired Christian names, which they placed in front of their single indigenous names. However, they did not necessarily regard the latter as Europeans regard a surname. Nor did they necessarily pronounce and spell their Christian names in the orthodox way. In Pita Tapo's case, Pita was not an indigenous 'first' name but represents Tapo's spelling and pronunciation of the English 'Peter'.

23 Minol et al. (2014: 1-2) write that the 'Namba 1 Rot', as they render it in Tok Pisin, led from Lorengau into the interior of the island and back to the 'central north coast'. They provide little detail on the route of the 'Namba 2 Rot'. 
form a unit with Lahan, but its people were generally hostile to Kampo's efforts. Kampo was able to convince some of the people of Lahan to build their houses in a new style, favour European clothing, and make other superficial changes, but the obstacles to altering the fundamental pattern of life were substantial.

Kampo and Tapo understood that the Usiai of Lahan were too few for any economic undertaking large enough to make a real difference in their lives. They also understood that, even though they were not as deep in the interior as the majority of Usiai villages, carrying any copra they produced to the coast would be gruelling, even for people accustomed to the often barely perceptible trails of the Manus interior, trails slippery with red clay and that constantly climbed and descended steeply, almost never crossing level ground. And they would have to carry through the same terrain the galvanised metal sheets from which they hoped to build European-style houses. In the end, Kampo and Tapo could not get beyond convincing people to adopt a few symbols of the European life, such as eating on tables decorated with flowers arranged in beer-bottle vases.

\section{The Admiralty Islands war veterans}

A group of Admiralty Islands men who had volunteered to fight the Japanese in mainland New Guinea under Australian leadership also tried to organise for change in the immediate postwar period. Sayau of Yiru, an Usiai village near the south coast, estimated that his unit killed about 50 Japanese to each five of their own men lost. Whether or not he exaggerated, he was proud of the prowess of the Manus soldiers. Yet even among these volunteers there was little feeling that this war concerned them directly. When the war ended and they had received their medals and citations, they were returned to their villages. Many soon became bitter, claiming that the Australians had failed to keep the promises made to them. William Matbe, whom many considered the most outstanding Manus volunteer, came from a north coast Usiai community. After the war, he led a group of about 20 veterans who actively pursued their grievances until 1949. They claimed they had been told that when the fighting was over they would receive some kind of substantial payment for their service and that the government had promised other special help and consideration. 
Schwartz was unable to confirm the validity of these claims, but Sayau also complained bitterly about a reward he did receive, and his complaint gives insight into the expectations of at least some of these former soldiers and the roots of their disappointment. Here is how Sayau described his grievance:

They [i.e. the Australians] said, 'We want to give you a citation and a medal'. 'What is this?', I thought. I don't know what this thing is that they called me up for and gave me. You white men, you know about these things, but we natives, we don't understand. I think it is worthless. But I should rejoice in it and I should wear it. Why? You didn't explain its meaning to me adequately. I don't understand. If I put it on without knowing what it is all about and you see me, you will laugh very hard at me.

Sayau told Schwartz that he threw away the medal and citation. This is plausible, for other similar incidents have been confirmed. Sayau was sure that either there was some hidden meaning in the medal that was deliberately withheld or that he and others had been tricked into accepting these worthless and unredeemable tokens in place of the promised payment. In either case, he believed he had been put into a position in which he afforded the white man secret amusement. He felt shamed and angry.

Sayau said the veterans group presented itself to the government on two occasions to ask that wartime promises be kept, but without success. Neither Matbe nor Sayau wanted to return to their villages to try to change them. Instead, they stayed in Lorengau. Matbe persuaded the men in the group to pool their money to start a store. They put together about $£ 300$ Australian, and the store failed after five months. The group then broke up. Sayau and Matbe stayed in Lorengau, but as employees, not entrepreneurs.

In the local movements described here one can see maturing the conditions, attitudes, and ideas in the midst of which the Paliau Movement emerged. Paliau's prewar efforts were small and tentative. After the war, Paliau's efforts embraced a dramatically larger geographic area, became more organisationally sophisticated, and presented a much enlarged program for change, as described in the next chapter. Paliau's intellect and pragmatic political skills help explain his success, but it is difficult-as we will seeto separate these qualities from his penchant and talent for imbuing his program with metaphysical meaning. 
This text is taken from Like Fire: The Paliau Movement and Millenarianism in Melanesia, by Theodore Schwartz and Michael French Smith, published 2021 by ANU Press, The Australian National University, Canberra, Australia.

doi.org/10.22459/LF.2021.04 